Article

\title{
Perceived Entrepreneurial Stress and Entrepreneurial Resilience; The Mediating Role of the Well-Being of Entrepreneurs and Moderating Role Perceived Online Social Support
}

Felix Kipkosgei (D)

check for

updates

Citation: Kipkosgei, F. Perceived Entrepreneurial Stress and Entrepreneurial Resilience; The Mediating Role of the Well-Being of Entrepreneurs and Moderating Role Perceived Online Social Support. Merits 2022, 2, 1-17. https:/ / doi.org/ $10.3390 /$ merits 2010001

Academic Editor: Tiziana Ramaci

Received: 3 December 2021

Accepted: 27 January 2022

Published: 30 January 2022

Publisher's Note: MDPI stays neutral with regard to jurisdictional claims in published maps and institutional affiliations.

Copyright: (C) 2022 by the author. Licensee MDPI, Basel, Switzerland. This article is an open access article distributed under the terms and conditions of the Creative Commons Attribution (CC BY) license (https:// creativecommons.org/licenses/by/ $4.0 /)$.
Independent Researcher, Eldoret 3931-30100, Kenya; felixkipkosgei@gmail.com

\begin{abstract}
This study investigated the effect of perceived entrepreneurial stress on entrepreneurial resilience with the well-being of an individual entrepreneur in mediating role and perceived online social support moderating this relationship. Using survey data collected from 204 entrepreneurs in two major towns in Kenya, considered entrepreneurial hubs were analyzed. To uncover this relationship, confirmatory factor analysis was conducted to test the discriminant validity of the measurement model. Hierarchical multiple regression was used to test four hypotheses in seven models to estimate direct, indirect and interaction effects. The results showed that perceived entrepreneurial stress and the well-being of individual entrepreneurs are significantly negatively related; this study also found out that the well-being of individual entrepreneurs and entrepreneurial resilience are positively related. For moderation effect, perceived online social support positively moderated the relationship between the well-being of individual entrepreneurs and entrepreneurial resilience. Finally, to test the indirect effect, bootstrapping analysis was used to identify mediation effects. The bootstrapping indirect test results revealed that the well-being of individual entrepreneurs mediates the relationship between perceived entrepreneurial stress and entrepreneurial resilience. This study outlines online communities as an avenue where entrepreneurs can access online social support that can facilitate entrepreneurial resilience during crises and to foster resilience among entrepreneurs despite adversity, entrepreneurs need to consider making a culture of seeking and providing social support online to fellow entrepreneurs and online communities.
\end{abstract}

Keywords: perceived entrepreneurial stress; the well-being of entrepreneur; perceived online social support; entrepreneurial resilience

\section{Introduction}

The rapid increase in the specialized journals in entrepreneurship studies has shown that the study in this field is slowly attracting attention among researchers. Scholars have recently diverted all their energy towards analyzing the antecedents, existing evidence and the impacts of the different aspects influencing entrepreneurial outcomes. There is vast academic literature and scholarly articles on the phenomenon of entrepreneurial behavior and the mediating factors in the developing world [1,2]. Despite this, there is still limited research that focuses on the business practices in small and medium enterprises; especially by some of the leading international journals and research groups.

The contributions made by new start-ups entrepreneurs in any economy will not go unrecognized. However, the rate at which most start-ups fail has drawn the attention of scholars such as Timmons et al. [3]. Entrepreneurs are at the forefront battling the COVID19 pandemic and serve as the most vulnerable group, and they must use their ingenuity to confront the problems facing them and be resilient by all means possible. There is a greater need for well-established and new businesses to survive both in the short term and long term, especially during this time of the pandemic. There is a need to adopt a flexible and 
entrepreneurial mindset to withstand the changing market conditions. Leaders and key stakeholders need to find ways of exploiting the huge potential of entrepreneurship by fostering innovations and focusing on improving the existing digital infrastructure.

With many entrepreneurs having not been spared during this COVID-19 pandemic era, Block et al. [4] explain that entrepreneurs have been exposed to a lot of uncertainty and their minds ring with lots of questions on what the future holds for them. Opportunities for entrepreneurial growth were shut, leading to increased entrepreneurial stress and raising concern over the well-being of entrepreneurs. Scholars such as Danna \& Griffin [5] stated that stress is a crucial antecedent of the well-being of an individual. Wincent et al. [6] on the other hand pointed out that stress related to entrepreneurship has also been linked to several entrepreneurial outcomes such as venture withdrawal. White and Gupta [7] in their research alluded to the fact that literature linking entrepreneurial stress and wellbeing is still undertheorized and needs more attention. This paper aims at bringing to light the psychological aspects of entrepreneurial activities, offering clarity on entrepreneurial stress and its impacts on entrepreneurial well-being and how it influences overall performance outcomes [6].

COVID-19 crisis regulations such as lockdowns and social distancing have forced the current entrepreneurial landscape to shift to online social platforms that involve entrepreneurs' participation in information sharing, creation, or distribution of content. Research shows that most business owners and small-scale entrepreneurs rely on the support provided by family, online communities and social groups [8,9]. Social support is an important aspect as it enables them to easily overcome the challenges that they face in their daily entrepreneurial activities. Steenkamp and Hyde-Clarke [10] explain the implications of modern technology and the entrepreneurial usage of digital platforms on the well-being and performance of entrepreneurs. This has also been echoed Dietrich [11] where the study established that online social support associated to online communities effectively helps to mediate stress and improve wellbeing.

This study lays its foundation on self-determination theory (SDT) Deci \& Ryan [12,13] which proposes that all humans have three basic psychological needs-autonomy, competence, and relatedness - that serve as an important predictor of growth and development. SDT postulates that an individual tendency towards well-being is innate, whether we attain well-being or not has to do with the environment and early socialization, which determines whether basic psychological needs will be satisfied or not. Evidence from various domains and empirical research according to SDT shows that well-being results from individuals' participation in intrinsically rewarding activities, from their degree of autonomous self-regulation in personal goal pursuits, and from their embracing of lifestyles. People's internal motivation and resilience are bolstered by environmental support for these three basic psychological needs: autonomy, competence, and relatedness. People can achieve the best possible psychological well-being when these basic psychological needs are met. These basic psychological needs improve well-being and strengthen resilience, as resilience is linked to behaviors of autonomy, self-realization, and self-regulation and resilient individuals demonstrate psychological autonomy in taking responsibility for their decisions Weston \& Parkin [14].

Recently, there is abundance of research on social support, however the theme of online support as a method of social support is still scarce [11]. In Kenya new innovations are taking over from old ways of doing business, and entrepreneurs are at the forefront of this historic transformation from analogue to digital, this has put Kenya on the map as one of the leading entrepreneurial hubs in Africa that utilizes the latest technology, Mureithi [15]. According to the Kenyan Ministry of Technology, internet connectivity across towns and cities in Kenya has helped entrepreneurs access the tools required to build sustainable and resilient businesses. Thus, with these developments, Kenyan entrepreneurs are starting to utilize online communities for social support and in the long run overcome stress related to entrepreneurship. 
Although many studies found a negative relationship between stress and wellbeing $[16,17]$, some studies failed to find any significant relationship, whereas other studies such as Dominika et al. [18], found a positive relationship between entrepreneurial related stressors and entrepreneurial wellbeing. These mixed empirical findings have raised concerns with regard to applying the findings in practice. Additionally, there is still scanty evidence from across the country of the relationship between these variables or the interaction of stress, and well-being in entrepreneurship arena. Most research studies have focused on Western countries and recently increasing attention has been given to Asian countries. It is therefore important to expand our understanding of different cultural backgrounds in which research on these topics is being undertaken.

In summary, this research study verges to fill in gaps in scholarly studies and literature by examining entrepreneurial stress and the importance of entrepreneurial wellbeing as an antecedent to entrepreneurial resilience, and attempts to lay ground work for further research on entrepreneurship and wellbeing [19].

It also attempts to understand the mechanisms of well-being on entrepreneurial resilience that can be moderated by online social support. Stressed entrepreneurs with low wellbeing are prone to venture withdrawal, by knowing the moderating effect of online social support, this research can form the basis for interventions that increase individual well-being and promote resilience among entrepreneurs by focusing on the mediating role of the wellbeing of individual entrepreneurs in this relationship. This study then describes the methods and presents the empirical results and finally, discusses the theoretical and practical implications of its findings; giving suggestions for future research.

\section{Theoretical Background and Hypotheses Development}

\subsection{Perceived Entrepreneurial Stress and Well-Being of Individual Entrepreneur}

Naik [20] describes perceived entrepreneurial stress as the harmful emotional or physical responses that come in when business or job requirements do not match the entrepreneurs' capabilities, resources, or needs. Entrepreneurial research typically focuses on firm-level outcomes like performance and growth, however idiosyncratic and personal aspects are also of utmost importance in entrepreneurship. Decades of research on the consequences of stress and how it affects entrepreneurs' well-being have offered ambiguous and differing conclusions. This literature review synthesizes different studies to establish the correlation between perceived entrepreneurial stress and the well-being of individual entrepreneurs. Entrepreneur satisfaction of basic psychological needs has been largely ignored in research even though it may have been vital to their well-being. Increased stress among entrepreneurs affects both mental and physical health, which in most cases leads to reduced performance and burnout among entrepreneurs. Stress is not always bad, but too much stress may affect one's well-being. Based on the way one sees a situation, what causes stress is based on our own situation, for instance, entrepreneurs can encounter stress from financial strain, work overload, and role ambiguity among others. Entrepreneurship comes with a lot of demands and commitments.

As an entrepreneur, when job-related demands rise, entrepreneurs' social life quality decreases. Seeing through the lens of Self-determination theory (SDT) in this study, innate psychological needs act as nourishment for quality of social life of an entrepreneur, perception of autonomy associated with an entrepreneur suffers while the quality of social life deteriorates since socialization opportunities become scarce resources for entrepreneurs, and thus lead to stressful conditions and in the long run affect entrepreneur's wellbeing. Thus, there is need to develop a cohesive theoretical framework that describes stress and an understanding of the stress framework in the context of entrepreneurship.

The entrepreneurial role is stressful, and the different types of stressors have a central role in an entrepreneur's well-being. Rauch, Fink \& Hatak [21] found out that entrepreneurs face a number of work and non-work-related stresses daily, including workload, competition, new knowledge demands, and resource constraints. Min [22] linked entrepreneurial stress to negative outcomes such as poor performance. On the other hand, linked work- 
related stress to increased levels of physiological strains and additionally entrepreneurial stress that has promoted unhealthy lifestyles and behaviors that harm entrepreneurial well-being in the long run [23-25].

Entrepreneurial stressors are the physiological and behavioral aspects that are detrimental, not only to the ventures of entrepreneurs but also their well-being, given that entrepreneurial work is intense, uncertain, stressful, and complex [26]. In their publication, Wiklund et al. [19] further added that these different aspects directly impact an entrepreneur's well-being. This is connected to a range of outcomes on individual stress that impacts firm performance and business growth.

Study by McCormick et al. [27] examined the within-person effects of work stressors among entrepreneurs. They classify the different entrepreneurial stress factors into hindrance and challenge stressors and how they suppress the entrepreneur's well-being, references [28] further contributed to emerging research aimed at understanding recovery processes for entrepreneurs and explained the psychological detachment processes that mediate the effects of stressors on an entrepreneur's well-being. Sonnentag and Fritz [29] introduced two different types of recovery experiences: work-related affective rumination and problem-solving pondering, which are the emotional and cognitive stress processes that reduce entrepreneurial stress. The two processes impact the overall well-being of the entrepreneur as they cope with the entrepreneurial stress. The literature, therefore, depicts that entrepreneurial stress has retrogressive impacts on all the different aspects of an individual's well-being. Thus, the following hypothesis was developed.

Hypothesis 1 (H1). Perceived entrepreneurial stress is negatively associated with the well-being of individual entrepreneur.

\subsection{The Well-Being of Individual Entrepreneur and Entrepreneurial Resilience}

Warr [30] defines well-being as the presence of happiness, satisfaction, enabling optimal psychological functioning of an individual. Entrepreneurs are an essential asset for the economy as they enable the creation of wealth and overall growth. They, however, face a litany of risks and repercussions of failure. Despite entrepreneurs often being depicted to be enthusiastic, passionate, and risk-taking, they are exposed to various negative affective states like stress, fear, and anxiety, which negatively affect their level of well-being. Affected well-being limits entrepreneurial resilience, which encompasses abilities like entrepreneurial judgment, decision making, opportunity recognition, stress management, and overall creativity [31].

The different aspects of resilience are measures of an individual's positive adaptation in the context of adversity. Conclusions arrived at by Dijkhuizen et al. [32] are that entrepreneur's resilience is a predictive value for business growth and that it is a product of an entrepreneur's well-being and the ability to mediate the impacts of stressors. Hayward et al. [33] also alluded to the fact that resilience is a vital component for entrepreneurs as it plays an important role during difficult times, thus overcoming failures and allowing for the possibility to start over stronger than before.

With entrepreneurs facing a myriad of pushbacks, including fear, apathy, desperation, financial setbacks, helplessness, and uncertainty, their well-being is often compromised in various ways. Well-being is conceptualized as the positive effects and satisfaction with life [32]. It is, therefore, a global assessment of an individual's quality of life depending on the chosen criteria, primarily focused on self-realization and full functionality. The outcomes of entrepreneurial resilience are based on an individual's well-being. According to Foo and colleagues [34] higher levels of well-being can recharge entrepreneurs' resilience and encourage entrepreneurs to continue persisting in challenging tasks that others often consider impossible. The entrepreneurial journey can be stressful and this can negatively affect their ability to be psychologically well and resilient. Although many programs addressing distress and well-being have been laid, little attention has been paid to the role of entrepreneurs' basic psychological needs, which within the entrepreneurial environ- 
ment can impact their well-being and resilience. Research grounded in SDT shows that environments that support people's basic psychological needs have been associated with reduced stress, such environments have also been associated with increased wellbeing and resilience [35]. According to Ryff \& Keyes [36], well-being encompasses multidimensional aspects such as autonomy, personal growth, purpose in life, and personal relations with others. As well-being is often associated with overcoming challenges and maintaining healthy coping strategies in response to stress, it relates closely to an individual's resilience [37].

In their publication, Cardon et al. [38] associated entrepreneurial well-being with increased motivation, openness to opportunities, and better abilities to cope with adversity and stress. On the other hand, resilience is defined by Korber \& McNaughton [39] as the general transformation and innovation to create a new state to recover from adversity, adapt positively, and achieve an evolution of the capacity to respond to adversity. A multidisciplinary perspective [40] explains that entrepreneurial resilience is related to an individual's well-being since resilience is an outcome of the per-son-entrepreneurial fit. Psychological capital is positively associated with subjective well-being and, as a result, positively influences entrepreneurial resilience and coping.

Given the significant effects of self-employment like strain due to long working hours, uncertainty, and work overloads, physical and emotional repercussions are bound to be experienced. Baron, Franklin \& Hmieleski [41] explain that such repercussions lead to a decline in psychological capital, which results in reduced resilience, a decline in the ability to cope with the different challenges faced in running a business. Therefore, we hypothesize that;

Hypothesis 2 (H2). The well-being of individual entrepreneurs is positively associated with entrepreneurial resilience.

\subsection{The Mediating Role of Well-Being of the Individual Entrepreneur}

An essential outcome of engagement in entrepreneurship is well-being. Given entrepreneurship's uncertain and highly dynamic nature, the journey is characterized by unforeseen challenges, adversity, and even failure [42]. The culmination of traversing the different challenges is synthesized in a scholarly perspective into the holistic concept of personal subjective well-being. Liang [43] defined well-being as either evaluative or hedonic, referring to the presence of a positive effect, the absence of negative aspects, and the experience of satisfaction and happiness. Entrepreneurial resilience is an outcome of the person and entrepreneurial fit and how the entrepreneur interacts with their environment [13], resilience is therefore dependent on the different psychological qualities of the individual in the event of adversity. Attaining equilibrium well-being has a positive association with entrepreneurial resilience and the ability to tolerate entrepreneurial stress, which is depicted in the form of risk tolerance, emotional resilience, and the ability to tolerate financial insecurity [44].

The conceptual tenets defined above are the essential aspects of the logic underpinning the correlation between entrepreneurial resilience and entrepreneurial stress. In their publication, Dominika, $\mathrm{W}$ et al. [18] explain that work-related stressors faced by entrepreneurs resulting from job insecurity, uncertainties, time pressure, extended working hours, and role ambiguity often have detrimental consequences on an individual's well-being. Workrelated stressors are the main precursors to entrepreneurial stress, which can only be managed when the well-being of the entrepreneur is at its best.

Furthermore, Santoro et al. [45] explain that entrepreneurial resilience is the overall capacity to overcome difficulties through a psychological and physical dynamic process and look forward to progress despite existing pushbacks. In their review, Baron, Franklin \& Hmieleski [41] explained that positive adaptation in the context of significant adversity requires suppression of entrepreneurial stress and the development of a positive attitude rather than fear, helplessness, desperation, and apathy. Well-being is an important mediating factor for resilience to be achieved. Therefore, sustained well-being is a significant 
precursor to entrepreneurial resilience and the development of coping abilities and tolerance for high-stress levels. Based on previous studies, I posit the following hypothesis;

Hypothesis 3 (H3). The well-being of individual entrepreneurs mediates the relationship between perceived entrepreneurial stress and entrepreneurial resilience.

\subsection{The Moderating Role of Perceived Online Social Support on the Relationship between the Well-Being of Individual Entrepreneurs and Entrepreneurial Resilience}

Social support encompasses both emotional and instrumental dimensions of the resources obtained through social interactions [46]. Perceived social support is vital at the workplace, be it support from friends, family, and coworkers or social support from online communities. Entrepreneurs are not always surrounded by coworkers; most entrepreneurs are solo business owners and thus undertake their day-to-day business-related activities on their own. Regardless of this situation, it is incredibly critical for entrepreneurs to lay a strong support system since social support plays a crucial role in the success of both new and established business owners. The day-to-day stress that entrepreneurs experience may affect their wellbeing. Social support is a key source of protection for them as it may reduce the negative effects of a stressful life. Furthermore, social support appears to be very important for entrepreneurs' process of recovery. Linking this study to self-determination theory, the extent to which entrepreneurs use online communities as a source of online social support is linked to one of the basic psychological needs-autonomy. Autonomy can be supported by listening to someone and providing someone with relevant information. These behaviors are likely to be supported in entrepreneurs' online communities, as these online communities' aims are to inform entrepreneurs, let them share experiences, support each other, and learn from each other. Therefore, whenever entrepreneurs seek social support from online communities, it is expected that the need for autonomy will be more fulfilled. In addition, online social support is expected to have a connection to perceived relatedness which according to SDT is one of the basic psychological needs. The need for relatedness becomes fulfilled when entrepreneurs have a sense of belonging and, are listened to, understood, and cared for by those whom they seek social support from. In addition, under self-determination theory (SDT), individuals are motivated if they receive adequate support as it fulfills their basic psychological needs. Internally, resilience can be considered as an intrinsic personality trait enabling individuals to adapt and survive in unfavorable conditions. It is expected that individuals may be motivated through social support from their online communities. Similarly, if entrepreneurs perceive that the people they seek or receive social support from are concerned about their entrepreneurial interest they may reciprocate with increased resilience.

However, during the COVID-19 pandemic, entrepreneurs' freedom to seek and receive social support from friends and coworkers was partially thwarted by restrictions put in place to curb the spread of the virus; this includes policies such as social distancing measures, lockdowns, and working from home [47]. Lockdown measures put entrepreneurs in a situation whereby they could not meet up in a face-to-face setting with professional advisors and mentors, which constitute a vital social support system [48,49].

The pandemic might have shut traditional offline social support spaces [50], however online spaces are opening up for entrepreneurs to engage and socialize online, and this online community provides an alternative source to the traditional offline social support. Kuhn \& Collins [51] defined online communities from an entrepreneurial point of view as a digital space where geographically dispersed individuals who are entrepreneurial-minded support each other by exchanging knowledge and availing resources or emotional support, Nambisan [52] terms these online communities as a key "digital infrastructure." Scholars have found out that entrepreneurs can obtain online social support more efficiently from online communities as compared to any other source [51].

Research studies such as Valenzuela et al. [53] allude that online social support is positively associated with personal well-being; they also went ahead to link it to outcomes 
such as improved life satisfaction, declining rate of depression, and improved quality of life. The same results have also been echoed by Kim and Lee [54] who established that social support from the online community enhances the well-being of individuals. It is through social support that Viseu et al. [55] reported that the negative effect of entrepreneurial stress on the well-being of individual entrepreneurs is neutralized; these results have been echoed over the past decade. Higher level of social support has associated with improved levels of well-being and reduced depression and stress [56]. With the pandemic, entrepreneurs are expected to devise new ways on how to be more resilient; in Shiri et al. [57] study, established that social support could change the expectations of an entrepreneur, thus promoting individuals to engage more in related entrepreneurial activities actively. In this study, online social support is inferred to strengthen the relationship between the well-being of individual entrepreneur and their entrepreneurial resilience. The study's conceptual model is illustrated in Figure 1 below, hence this study proposes the following hypothesis;

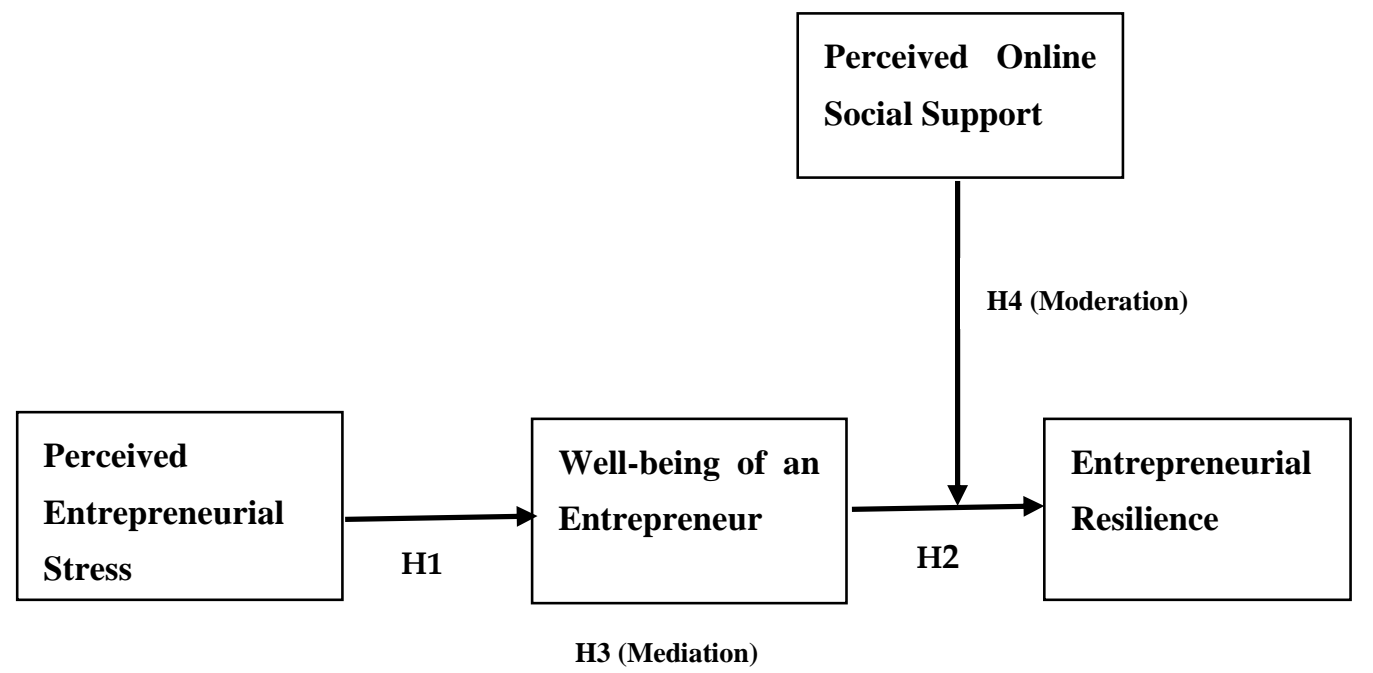

Figure 1. Hypothetical research model.

Hypothesis 4 (H4). Perceived online social support positively moderates the relationship between the well-being of individual entrepreneurs and entrepreneurial resilience such that the relationship is stronger when there is high online social support.

\section{Methods}

\subsection{Sample and Procedure}

The research study was conducted among entrepreneurs in two major towns in Kenya, that is Nairobi and Eldoret town; which Park et al. and Tubey et al. [58,59] consider as major entrepreneurial hubs since they actively engage in retailing and operating businesses. The participants were recruited through convenient sampling method. Data was collected using a structured survey questionnaire developed for data collection, and this was administered through our research assistants within the two towns. The data collection exercise was conducted between the month of February and March 2021; this exercise took approximately one and half months. First, our research assistants approached participants and introduced themselves; they also took some time to explain what the study was about by showing them an introductory letter by the researcher; after that, the research assistants forwarded surveys to those participants who had agreed to take part in the study. The participants were assured that participation was voluntary, that their responses would be confidential, and the data collected would only be used for research purposes.

The questionnaire used in the study was divided into five parts (1) demographics, (2) Perceived entrepreneurial stress, (3) entrepreneurial well-being, (4) entrepreneurial resilience, (5) perceived online social support. All five sections were mandatory. A total 
of 250 survey questionnaires were shared with the participants, we received 204 complete responses; this translated to an $81.6 \%$ response rate, the sample size used was appropriate, this is after calculating the minimum sample size by using $G^{*}$ Power version 3.1.9.7 Kang [60] that has been widely utilized to calculate the appropriate sample size. Respondents' mean age was 31 years, $51 \%$ of the sample were male, and $49 \%$ were female. About $6 \%$ of the sample had a high school education, $28 \%$ had a college degree, $41 \%$ had a university degree, $19 \%$ had a master's degree, and $6 \%$ had a doctoral degree. The mean number of years that their businesses had been in existence was 3.1 years.

\subsection{Measures}

Response options of the items used in all the variables were on a five-point Likert-type scale, where $1=$ strongly disagree, through $5=$ strongly agree. The complete items are presented in Appendix A.

\subsubsection{Perceived Entrepreneurial Stress}

Perceived entrepreneurial stress was measured with the responses to the five-item entrepreneurial stress scale $(\alpha=0.72)$ adapted by Fatoki [61]. A sample item is "As an entrepreneur, I have a heavy workload every day."

\subsubsection{Well-Being of Entrepreneur}

The well-being of entrepreneurs was measured with the responses to the eight-item entrepreneurial well-being scale $(\alpha=0.88)$ adapted from Diener et al. [62]. A sample item is "As an entrepreneur, I lead a purposeful and meaningful life."

\subsubsection{Perceived Online Social Support}

Perceived Online social support was measured with the responses to the four-item perceived online social support scale $(\alpha=0.74)$ adapted from Frison \& Eggermont [63]. A sample item is "As an entrepreneur, I can find the emotional help and support that I need online/Internet."

\subsubsection{Entrepreneurial Resilience}

Entrepreneurial resilience was measured with the responses to the 4-item entrepreneurial resilience scale $(\alpha=0.86)$ adapted from Sinclair and Wallston [64]. A sample item is "As an entrepreneur, I believe I can grow in positive ways by dealing with difficult situations.

\subsubsection{Control Variables}

This study controlled for the effects of gender since [65] found out that gender difference is likely to affect the level of social support that one can receive. It also controlled for age, given that one's online social activity is likely to vary with age difference [66]. The effect of business age was controlled since Lafuente et al. [67] established that the length in which a business has been in existence is likely to affect one's entrepreneurial reliance level. Finally, this study controlled for education level since human capital such as experience and education has been argued to affect the growth, success, resilience, and stability of a business venture [68-70].

\subsubsection{Common Method Bias}

Since all the variables were assessed at the same time, the results might have been affected by common method bias (CMB); in an effort to minimize this, this study adopted the recommendation by Podsakoff et al. [71] and conducted Harman's single-factor test. All the items of the study variables were loaded into an exploratory factor analysis. The results indicate that no single factor explained more than $29 \%$ of the covariance among the variables. This gave an indication that Possible CMB was not a threat in this study. 


\subsection{Analytical Strategy}

Prior to performing any analysis in this study, the mediating variable and moderator were mean-centered before creating the product term, in order to reduce the collinearity between the variables of the interaction term. Then the variance inflation factor (VIF) was calculated, all the VIF values were below 10 (see Table 3), this indicated that multicollinearity did not pose any potential threat to the analysis Hocking \& Pendleton [72]. Then the confirmatory factor analysis (CFA) was conducted to determine the distinctiveness of the variables under study. This was then followed by calculation chi-square model comparison test using Data Analysis and Statistical Software, (Stata Corp., College Station, TX, USA) STATA 14.1. The unit of analysis was individual-level analysis. Hierarchical multiple regression analyses were used to test the direct and interaction effects. Concerning the indirect effect, the bootstrapped indirect effect proposed by Preacher and Hayes was employed to test the mediating effect proposed by Hypothesis 3 .

\section{Results}

\subsection{Descriptive Statistics}

The mean, standard deviation, and correlations of all variables are summarized in Table 1 . The internal reliability of all the measures was within the acceptable standards $(0.72-0.88)$.

Table 1. Means, standard deviations, correlations, and reliabilities.

\begin{tabular}{|c|c|c|c|c|c|c|c|c|c|c|}
\hline & Mean & SD & 1 & 2 & 3 & 4 & 5 & 6 & 7 & 8 \\
\hline 1. Gender $(F=0 ; M=1)^{a}$ & 0.51 & 0.50 & - & & & & & & & \\
\hline 2. Age & 31.99 & 5.97 & -0.09 & - & & & & & & \\
\hline 3. Education $\mathrm{b}$ & 3.32 & 1.31 & 0.05 & $0.40^{* *}$ & - & & & & & \\
\hline 4. Business age ${ }^{c}$ & 3.10 & 2.18 & 0.02 & $0.19^{* *}$ & 0.02 & - & & & & \\
\hline 5. Stress & 3.57 & 0.70 & 0.05 & -0.02 & -0.03 & 0.07 & 0.72 & & & \\
\hline 6. wellbeing & 3.80 & 0.65 & $-0.16^{*}$ & -0.08 & -0.05 & 0.08 & $-0.04^{* *}$ & 0.88 & & \\
\hline 7. Resilience & 3.61 & 0.66 & $0.03 * *$ & -0.02 & 0.05 & -0.35 & 0.01 & $0.43^{* *}$ & 0.86 & \\
\hline 8. Online support & 3.94 & 0.56 & -0.06 & 0.08 & 0.08 & 0.02 & 0.01 & $0.43^{* *}$ & 0.36 * & 0.74 \\
\hline
\end{tabular}

Note: $\mathrm{N}=204 .{ }^{*} p<0.05 ;{ }^{* *} p<0.01$. Reliability alpha $(\alpha)$ coefficients are reported in diagonal; ${ }^{\mathrm{a}} \mathrm{M}=$ male $\mathrm{F}=$ female,${ }^{\mathrm{b}}$ Education $=$ years of education; ${ }^{\mathrm{c}}$ Business age $=$ number of years the business has existed in years.

\subsection{Confirmatory Factor Analysis and Chi-Square Difference Test}

Before testing the hypothesized research model, this study carried out confirmatory factor analysis (CFA). The comparative fit index (CFI), Tucker Lewis index (TLI), and the root mean square error of approximation (RMSEA) was used to assess the model fit. The cutoffs for the model fit indices according to ref. [73] are; comparative fit index (CFI) and Tucker-Lewis index (TLI) $\geq 0.95$, root-mean-square error of approximation (RMSEA) $\leq 0.05$. Results from this analysis indicated that the hypothesized model had the best fit $\left(\chi^{2}=207.23, \mathrm{df}=146 ; \mathrm{CFI}=0.96 ; \mathrm{TLI}=0.96\right.$; and RMSEA $\left.=0.05\right)$.

The results recorded in Table 2 below show that all the alternative models (3-factor model ${ }^{\mathrm{a}}$, 2-factor model ${ }^{\mathrm{b}}$,1-factor model ${ }^{\mathrm{c}}$ ) significantly differed from the hypothesized model; this meant that the hypothesized model showed the best goodness of fit indicator.

\subsection{Hypothesis Testing}

This study used the hierarchical multiple regression analysis to test the hypothesized relationships. The results reported from the hierarchical regression analysis are provided in Table 3. Hypothesis 1 posited a negative relationship between perceived entrepreneurial stress and the well-being of individual entrepreneurs. Regression results in Table 3 supported this hypothesis ( $\beta=-0.04, p<0.01$; Model 2$)$ after controlling for effects of age, gender, education level, and age of business. Hypothesis 2 predicted that the well-being of individual entrepreneurs is positively associated with entrepreneurial resilience. The results showed that the well-being of individual entrepreneurs has a significant positive 
influence on entrepreneurial resilience $(\beta=0.37, p<0.001$; Model 6$)$, which supported Hypothesis 2.

Table 2. Model fit statistics for measurement models.

\begin{tabular}{ccccccccc}
\hline Measurement Model & $\mathbf{X}^{\mathbf{2}}$ & $\mathbf{D f}$ & $\boldsymbol{p}$-Value & $\boldsymbol{\Delta} \mathbf{X}^{\mathbf{2}}$ & $\boldsymbol{\Delta d f}$ & TLI & CFI & RMSEA \\
\hline Hypothesized model $^{2}$ & 207.23 & 146 & 0.00 & & & 0.96 & 0.96 & 0.05 \\
3-factor model $^{\text {a }}$ & 302.92 & 149 & 0.00 & $95.69^{* *}$ & 3 & 0.89 & 0.91 & 0.07 \\
2-factor model $^{\text {b }}$ & 600.49 & 151 & 0.00 & $393.26^{* * *}$ & 5 & 0.70 & 0.74 & 0.12 \\
1-factor model $^{\text {c }}$ & 757.60 & 152 & 0.00 & $550.37^{* * *}$ & 6 & 0.88 & 0.90 & 0.14 \\
\hline
\end{tabular}

Note: $\mathrm{N}=204{ }^{* *} p<0.01 ;{ }^{* * *} p<0.001{ }^{\text {a }}{ }^{*}$ Three-factor model with Perceived entrepreneurial stress and online social support on the same factor. ${ }^{b}$ Two-factor model with entrepreneurial stress, entrepreneurial well-being, and online social support on the same factor. ${ }^{c}$ One-factor model with entrepreneurial stress, entrepreneurial well-being, entrepreneurial resilience, and online social support same factor.

Table 3. Hierarchical multiple regression for the well-being of entrepreneurs and entrepreneurial resilience.

\begin{tabular}{|c|c|c|c|c|c|c|c|}
\hline & \multicolumn{5}{|c|}{ Well-Being of Entrepreneur } & \multicolumn{2}{|c|}{ Entrepreneurial Resilience } \\
\hline & M 1 & M 2 & M 3 & M 4 & M 5 & M 6 & M 7 \\
\hline Intercept & $4.21^{* * *}$ & $2.46^{* * *}$ & $3.48^{* * *}$ & $3.53^{* * *}$ & $1.89 * * *$ & $0.97^{* * *}$ & $3.97^{* * *}$ \\
\hline \multicolumn{8}{|l|}{ Controls } \\
\hline Age & -0.01 & -0.14 & 0.00 & 0.00 & -0.00 & 0.04 & 0.00 \\
\hline Gender & $-0.22 *$ & $-018 *$ & -0.02 & 0.04 & 0.07 & 0.14 & 0.14 \\
\hline Education & -0.00 & -0.02 & 0.00 & 0.22 & 0.01 & 0.02 & 0.19 \\
\hline \multicolumn{8}{|l|}{ Business age } \\
\hline $\begin{array}{l}\text { Independent } \\
\text { variable }\end{array}$ & 0.03 & 0.03 & 0.00 & -0.01 & -0.01 & -0.02 & -0.22 \\
\hline $\begin{array}{c}\text { PES } \\
\text { Moderator }\end{array}$ & & $-0.04^{* *}$ & -0.00 & & 0.01 & & 0.34 \\
\hline POSS & & $0.51^{* * *}$ & $0.31^{* * *}$ & & $0.43^{* * *}$ & $0.24^{* *}$ & -0.01 \\
\hline \multicolumn{8}{|l|}{ Interaction } \\
\hline $\mathrm{EW} \times \mathrm{POSS}$ & & & 0.26 & & & & $0.23^{* *}$ \\
\hline \multicolumn{8}{|l|}{ Mediator } \\
\hline EW & & & & & & $0.37^{* * *}$ & $0.06^{*}$ \\
\hline Max VIF & 1.13 & 1.09 & 1.68 & 1.13 & 1.09 & 1.17 & 1.68 \\
\hline F & 2.20 & $9.61^{* * *}$ & $9.89^{* * *}$ & 0.23 & $5.05^{* * *}$ & $8.72^{* * *}$ & $7.45^{* * *}$ \\
\hline $\mathrm{R}^{2}$ & 0.04 & 0.22 & 0.96 & 0.01 & 0.13 & 0.24 & 0.27 \\
\hline Adjusted $R^{2}$ & 0.02 & 0.20 & 0.95 & -0.02 & 0.11 & 0.21 & 0.24 \\
\hline$\Delta \mathrm{R}^{2}$ & & 0.18 & 0.74 & & 0.12 & 0.11 & 0.03 \\
\hline
\end{tabular}

Note: $\mathrm{N}=204 .{ }^{*} p<0.05 ;{ }^{* *} p<0.01 ;{ }^{* * *} p<0.001$. Perceived entrepreneurial stress (PES); Entrepreneurial wellbeing (EW); Perceived online social support (POSS).

To test for the mediating effect postulated by Hypothesis 3 (Well-being of individual entrepreneur mediates the relationship between perceived entrepreneurial stress and entrepreneurial resilience), this study utilized the bootstrapping indirect effect [74]. As reference [75] recommendation, 10,000 bootstrap samples from the data set were created, and a $95 \%$ confidence interval for the indirect effect estimates was used. The results demonstrated a significant indirect effect of perceived entrepreneurial stress on entrepreneurial resilience through the well-being of individual entrepreneurs, the coefficient was 0.15 , and $95 \%$ CI $(0.024,0.085)$ excluding Zero. Therefore, it confirms that Hypothesis 3 is supported.

Finally, Hypothesis 4 (Perceived online social support moderates the relationship between the well-being of individual entrepreneurs and entrepreneurial resilience such that the relationship is stronger when there is high online social support) was tested. To test Hypothesis 4, an interaction term was computed between the well-being of individual entrepreneurs and perceived online social support. Results in Table 3 show that the interaction term was positive and statistically significant $(b=0.23, p<0.01$; Model 7$)$. Figure 2 illustrates the results of a simple slope analysis that show the relationship between 
the well-being of individual entrepreneur, entrepreneurial resilience under high online social support condition was statistically significant $(b=0.28, \mathrm{SE}=0.06, p<0.001)$, and that the relationship was not statistically significant when online social support was low $(\mathrm{b}=0.12, \mathrm{SE}=0.08, p=0.13)$. Since the simple slope under the high and low online social support conditions differed, these results reconfirmed Hypothesis 4.

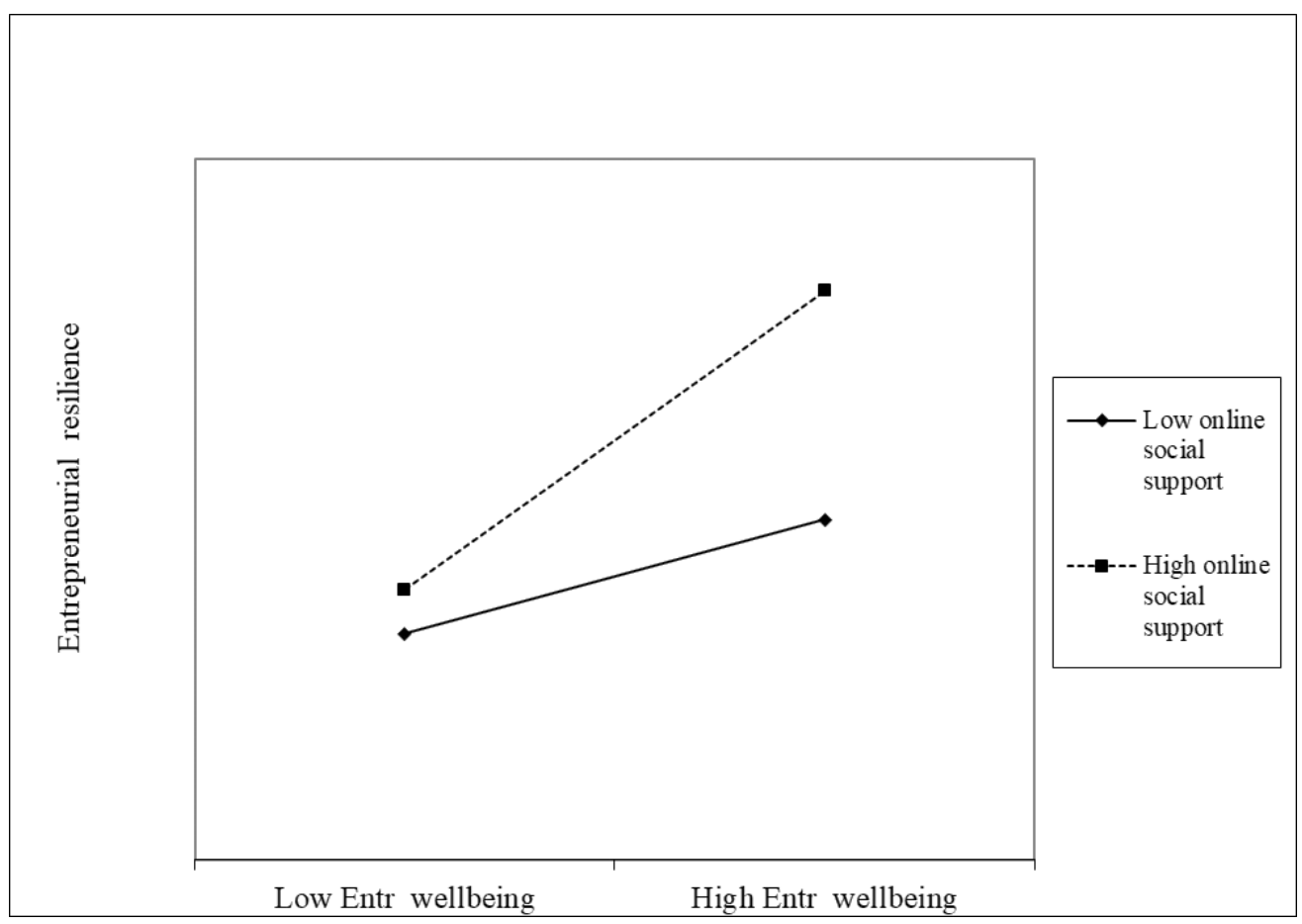

Figure 2. The moderating effect of online social support on the relationship between and well-being of individual entrepreneur and Entrepreneurial resilience.

\section{Discussion}

Entrepreneurial stress during the COVID-19 pandemic left many entrepreneurs with limited growth opportunities; there was also a rise in entrepreneurial stress during this pandemic era. It is also during these unprecedented times that many entrepreneurs were affected both emotionally and financially, due to entrepreneurial-related stress and the collapse of their businesses, respectively. Entrepreneurs are, therefore, likely to need support to conduct their day-to-day entrepreneurial activities, with this said there is still lack of desirable avenues from where entrepreneurs can obtain support to create the desired entrepreneurial action, especially when offline social support networks are not accessible.

Despite the stress that entrepreneurs undergo, they still associate themselves with a strong level of resilience. It is unlikely that their perceived abilities to overcome stress associated with entrepreneurship exist as mere coincidences or by chance. This study demonstrates the likelihood that online social support, namely that from the online community, plays a role in enhancing entrepreneurial resilience perception. Entrepreneurs can also enhance friendship online by fostering connections in online social platforms and online communities.

There has been increasing attention towards entrepreneurial studies, especially during the pandemic and the call for scholars to look more into how digital transformation has played a part during the pandemic period [76]. During these unprecedented times, researchers need to take a look into what drives entrepreneurial resilience [77].

Specifically, this study investigated and found out that the well-being of individual entrepreneurs provides a mediating mechanism that links perceived entrepreneurial stress and entrepreneurial resilience. Furthermore, this study examined the moderating role of perceived online social support on the relationship between the well-being of individual 
entrepreneurs and entrepreneurial resilience. This study recognizes that entrepreneurs can build social capital through both offline and online social networks and that these two types of social capital can play a vital role in the entrepreneurship journey. Thus, entrepreneurs can convert weak ties that are commonly associated with offline social support to stronger ties by leveraging online social networking to seek social support. Since seeking online social support can provide a tailor-made response for entrepreneurs who frequently engage in interaction with the support seeker or support providers, this comes in handy in times of high uncertainty [47]. Additionally, with regard to this research findings show that entrepreneurial stress depletes psychological resources, thus a key concern is how to rebuild these capabilities, which should be examined as a means of mitigating the effects of stress. This study concluded that psychological wellbeing can play a mediating role in stress mitigation by promoting positive psychological responses to stressful situations this may help them to build resilience against stressors among entrepreneurs as they seek to navigate through a crisis brought about by the pandemic. All four hypotheses were supported.

\subsection{Theoretical Contributions}

This study makes its contribution to literature in multiple ways. Based on the findings of the empirical analysis, this study derived the following theoretical and practical implications:

First, this paper has heed to call by Wiklund et al. [19] to look into entrepreneurship and well-being as an opportunity for future research, they further alluded to the fact that well-being as a variable has been there for decades, but entrepreneurial well-being has been given very little attention, hence this study is a contribution to entrepreneurial well-being literature. Additionally, many researchers have utilized well-being as a dependent variable to entrepreneurial outcomes. In contrast, other researchers such as Wright et al. [78] have assessed its moderating role; these entrepreneurial well-being studies tend to focus only on the direct and moderating role of entrepreneurial well-being. Meanwhile, few studies by [79] have given attention to mediating role of entrepreneurial well-being; thus, this study comes in handy to fill this gap. Thus, this study continues to link the literature surrounding entrepreneurial stress and its impact on well-being by discussing stress within the context of entrepreneurial processes, Rauch et al. [21].

Secondly, the aspect of resilience plays a critical role in entrepreneurship research; data used in this study was collected during the COVID-19 pandemic period, where there are many entrepreneurial uncertainties and increased entrepreneurial stress [80]. Findings from this study show that entrepreneurs are likely to remain optimistic in the face of adversity and setbacks such as stress related to entrepreneurship and the pandemic. These results are in line with Branzei \& Abdelnour, and Dewald et al. [81,82], this means that entrepreneurs starting businesses during challenging times are likely to come up or discover ways to overcome constraints and become more resilient.

Finally, Merion [83] noted that traditional offline social support has received much attention leaving behind the influence of online social support, which still needs more scrutiny due to scanty literature in this field; this study hypothesized that online social support would positively moderate the relationship between the well-being of individual entrepreneur and entrepreneurial resilience and the analysis revealed that high level of online social support strengthens that relationship. During this pandemic era loneliness due to social distancing and lockdowns are likely to affect mental health and wellbeing of entrepreneurs, and in the long-run it may lead to poor relationships with others if they are used to socializing and seeking support traditionally as opposed to online. Additionally, lonely individuals have low ability to tolerate stress, so their level of well-being is also low. This research contributes to the debate around where entrepreneurs can access support during crises $[47,84]$. In addition, this study outlines online communities as an avenue where entrepreneurs can access online social support that can facilitate entrepreneurial resilience during crises and help entrepreneurs reduce entrepreneurial uncertainty $[85,86]$. Finally, this study responds to a call by Choi et al. [87] for future research to identify other 
important moderators and mediators that can help entrepreneurs pursue and prevail in their new business.

\subsection{Practical Implications}

In addition, this study presented the following practical implications. The first observation is that online social support is essential in improving one's entrepreneurial resilience. Thus, to foster resilience among entrepreneurs despite adversity, entrepreneurs need to consider making a culture of seeking and providing social support online to fellow entrepreneurs and online communities.

Secondly, organizations and entrepreneurship training centers should take into consideration the importance of the well-being of entrepreneurs and emphasize this aspect, especially during the crisis since it is through entrepreneur's well-being that start-ups and entrepreneurs are likely to remain optimistic in the face of adversity and setbacks such as stress related to entrepreneurship.

Finally, Governments and organizations should encourage digitization of entrepreneurship since this research has shown that when individual entrepreneurs utilize online communities for social support, their well-being is enhanced and thus they become more resilient in the long run, this implication echoes the call by Nambisan et al. [88].

\subsection{Limitations and Future Research}

Some limitations are associated with this research work. First, this study is based on cross-sectional data which was collected from a single country that could be a challenge. In future, we recommend longitudinal cross-country datasets and future research may replicate these findings with different samples and across different country contexts that have different cultural backgrounds to support or challenge the outcomes of this model.

Secondly, this study used self-reported questionnaire administered at the same time to the same source, thus common method bias (CMB) might be a potential threat and result in inflated relationships because of single-source effects therefore results should be interpreted with caution because the respondents might have been biased while self-reporting or responding to the questionnaire, even though Harman's one-factor test suggests that common method bias may not be an issue in this study. This study suggests that future studies employ time-lagged data as a way of minimizing CMB.

Thirdly, given that data relating to entrepreneurial stress, entrepreneurial well-being, seeking and receiving social support online, and entrepreneurial resilience was collected during the current COVID-19 crisis, it is uncertain how generalizable knowledge from this crisis is to other crises encountered with respect to entrepreneurship literature.

Finally, data utilized in this study relates to the traditional "brick-and-mortar" type of entrepreneurship. For future research opportunities, this study suggests utilizing data from online entrepreneurs, who in most cases are associated with seeking social support from online communities as compared to traditional entrepreneurs.

\section{Conclusions}

Finally, this study found that online social support played positive moderating roles in enhancing entrepreneurial resilience. In addition, this study also highlighted the important mediating role played by entrepreneurial well-being in linking the relationship between entrepreneurial stress and entrepreneurial resilience. Despite its limitations, this research on substantial moderators and mediators provides useful insights for entrepreneurs that wish to enhance their entrepreneurial resilience.

Funding: This research received no external funding.

Institutional Review Board Statement: Not applicable.

Informed Consent Statement: Written informed consent has been obtained from the participants to publish this paper. 
Data Availability Statement: Study did not report any data.

Conflicts of Interest: The author declares no conflict of interest.

\section{Appendix A. Measurement Items}

1. Perceive Entrepreneurial stress measures [61]

1. I have a heavy workload every day.

2. Competition in my line of business is intense.

3. There is a rapid development of products in my line of business and in my line of business that I need to always update my knowledge.

4. I spend a lot of time and energy managing the responsibilities related to my business.

5. I feel nervous that I do not have sufficient funds to operate my business.

2. Wellbeing of entrepreneur [62]

1. I lead a purposeful and meaningful life.

2. My social relationships are supportive and rewarding.

3. I am engaged and interested in my daily activities.

4. I actively contribute to the happiness and well-being of others.

5. I am competent and capable in the activities that are important to me.

6. I am a good person and live a good life.

7. I am optimistic about my future.

8. People respect me.

3. Perceived Online social support [63]

1. I can find help online/Internet.

2. I can find the emotional help and support that I need online/Internet.

3. I can talk with someone online/Internet about my problems.

4. I can find someone online/on Internet that helps me make decisions.

4. Entrepreneurial resilience [64]

1. I believe I can grow in positive ways by dealing with difficult situations.

2. I actively look for ways to replace the losses I encounter in life.

3. I look for creative ways to alter difficult situations.

4. Regardless of what happens to me, I believe I can control my reaction to it.

\section{References}

1. George, G.; Corbishley, C.; Khayesi, J.N.; Haas, M.R.; Tihanyi, L. Bringing Africa in: Promising directions for management research. Acad. Manag. J. 2016, 59, 377-393. [CrossRef]

2. Jones, P.; Maas, G.; Dobson, S.; Newbery, R.; Agyapong, D.; Matlay, H. Entrepreneurship in Africa, part 1: Entrepreneurial dynamics in Africa. J. Small Bus. Enterp. Dev. 2018, 25, 346-348. [CrossRef]

3. Timmons, J.A.; Spinelli, S.; Tan, Y. New Venture Creation: Entrepreneurship for the 21st Century; McGraw-Hill/Irwin: New York, NY, USA, 2004; Volume 6.

4. Block, J.H.; Fisch, C.; Hirschmann, M. The determinants of bootstrap financing in crises: Evidence from entrepreneurial ventures in the COVID-19 pandemic. Small Bus. Econ. 2021, 58, 867-885. [CrossRef]

5. Danna, K.; Griffin, R.W. Health and Well-Being in the Workplace: A Review and Synthesis of the Literature. J. Manag. 1999, 25, 357-384. [CrossRef]

6. Wincent, J.; Örtqvist, D.; Drnovsek, M. The entrepreneur's role stressors and proclivity for a venture withdrawal. Scand. J. Manag. 2008, 24, 232-246. [CrossRef]

7. White, J.V.; Gupta, V.K. Stress and Well-Being in Entrepreneurship: A Critical Review and Future Research Agenda. Entrep. Small Bus. Stressors Exp. Stress Well-Being 2020, 18, 65-93. [CrossRef]

8. Hoang, H.; Antoncic, B. Network-based research in entrepreneurship: A critical review. J. Bus. Ventur. 2003, 18, 165-187. [CrossRef]

9. Jack, S.L. Approaches to studying networks: Implications and outcomes. J. Bus. Ventur. 2010, 25, 120-137. [CrossRef]

10. Steenkamp, M.; Hyde-Clarke, N. The use of Facebook for political commentary in South Africa. Telemat. Inform. 2014, 31, 91-97. [CrossRef]

11. Dietrich, C. Online social support: An effective means of mediating stress. Inq. J. 2010, $2,5$. 
12. Deci, E.L.; Ryan, R.M. The general causality orientations scale: Self-determination in personality. J. Res. Personal. 1985, 19, 109-134. [CrossRef]

13. Ryan, R.M.; Deci, E.L. Intrinsic and extrinsic motivations: Classic definitions and new directions. Contemp. Educ. Psychol. 2000, 25, 54-67. [CrossRef]

14. Weston, K.J.; Parkin, J.R. From at-risk to at-promise: The resilience movement. Encycl. Cross-Cult. Sch. Psychol. 2010, 808-815. [CrossRef]

15. Mureithi, M. The Internet Journey for Kenya: The Interplay of Disruptive Innovation and Entrepreneurship in Fueling Rapid Growth. In Digital Kenya: An Entrepreneurial Revolution in the Making; Palgrave Macmillan: London, UK, $2017 ;$ pp. 27-44. [CrossRef]

16. Wersebe, H.; Lieb, R.; Meyer, A.H.; Hofer, P.; Gloster, A.T. The link between stress, well-being, and psychological flexibility during an Acceptance and Commitment Therapy self-help intervention. Int. J. Clin. Health Psychol. 2018, 18, 60-68. [CrossRef] [PubMed]

17. Zarbova, B.; Karabeliova, S. Stress and well-being. In Proceedings of the 12th International Conference Days of Applied Psychology, Niš, Serbia, 30 September 2016; pp. 1-11.

18. Dominika, W.; Stephan, U.; Weinberger, E.; Wegge, J. Entrepreneurs' stressors and well-being: A recovery perspective and diary study. J. Bus. Ventur. 2021, 36, 106016

19. Wiklund, J.; Nikolaev, B.; Shir, N.; Der Foo, M.; Bradley, S. Entrepreneurship and well-being: Past, present, and future. J. Bus. Ventur. 2019, 34, 579-588. [CrossRef]

20. Naik, B. Entrepreneurial Role Stress among Women Working in Mahila Bachat Gat (Women self-help group). Gold. Res. Thoughts 2012, 22, 49-52.

21. Rauch, A.; Fink, M.; Hatak, I. Stress Processes: An Essential Ingredient in the Entrepreneurial Process. Acad. Manag. Perspect. 2018, 32, 340-357. [CrossRef]

22. Min, P.G. Problems of Korean immigrant entrepreneurs. Int. Migr. Rev. 1990, 24, 436-455. [CrossRef]

23. Boswell, W.R.; Olson-Buchanan, J.B.; LePine, M.A. Relations between stress and work outcomes: The role of felt challenge, job control, and psychological strain. J. Vocat. Behav. 2004, 64, 165-181. [CrossRef]

24. Webster, J.R.; Beehr, T.A.; Christiansen, N.D. Toward a better understanding of the effects of hindrance and challenge stressors on work behavior. J. Vocat. Behav. 2010, 76, 68-77. [CrossRef]

25. Lewin-Epstein, N.; Yuchtman-Yaar, E. Health Risks of Self-Employment. Work Occup. 1991, 18, 291-312. [CrossRef]

26. Bliese, P.D.; Edwards, J.R.; Sonnentag, S. Stress and well-being at work: A century of empirical trends reflecting theoretical and societal influences. J. Appl. Psychol. 2017, 102, 389-402. [CrossRef] [PubMed]

27. McCormick, B.W.; Reeves, C.J.; Downes, P.E.; Li, N.; Ilies, R. Scientific Contributions of Within-Person Research in Management: Making the Juice Worth the Squeeze. J. Manag. 2018, 46, 321-350. [CrossRef]

28. Williamson, A.J.; Battisti, M.; Leatherbee, M.; Gish, J.J. Rest, zest, and my innovative best: Sleep and mood as drivers of entrepreneurs' innovative behavior. Entrep. Theory Pract. 2019, 43, 582-610. [CrossRef]

29. Sonnentag, S.; Fritz, C. Recovery from job stress: The stressor-detachment model as an integrative framework. J. Organ. Behav. 2014, 36, S72-S103. [CrossRef]

30. Warr, P. Self-employment, personal values, and varieties of happiness-unhappiness. J. Occup. Health Psychol. 2018, 23, 388. [CrossRef]

31. Corner, P.D.; Singh, S.; Pavlovich, K. Entrepreneurial resilience and venture failure. Int. Small Bus. J. Res. Entrep. 2017, 35, 687-708. [CrossRef]

32. Dijkhuizen, J.; Gorgievski, M.; van Veldhoven, M.; Schalk, R. Well-Being, Personal Success and Business Performance Among Entrepreneurs: A Two-Wave Study. J. Happiness Stud. 2017, 19, 2187-2204. [CrossRef]

33. Hayward, M.L.; Forster, W.R.; Sarasvathy, S.D.; Fredrickson, B.L. Beyond hubris: How highly confident entrepreneurs rebound to venture again. J. Bus. Ventur. 2010, 25, 569-578. [CrossRef]

34. Foo, M.-D.; Uy, M.A.; Baron, R.A. How do feelings influence effort? An empirical study of entrepreneurs' affect and venture effort. J. Appl. Psychol. 2009, 94, 1086-1094. [CrossRef] [PubMed]

35. Weinstein, N.; Ryan, R.M. A self-determination theory approach to understanding stress incursion and responses. Stress Health 2011, 27, 4-17. [CrossRef]

36. Ryff, C.D.; Keyes, C.L.M. The structure of psychological well-being revisited. J. Personal. Soc. Psychol. 1995, 69, 719. [CrossRef]

37. He, F.; Cao, R.; Feng, Z.; Guan, H.; Peng, J. The Impacts of Dispositional Optimism and Psychological Resilience on the Subjective Well-Being of Burn Patients: A Structural Equation Modelling Analysis. PLoS ONE 2013, 8, e82939. [CrossRef]

38. Cardon, M.S.; Gregoire, D.A.; Stevens, C.E.; Patel, P.C. Measuring entrepreneurial passion: Conceptual foundations and scale validation. J. Bus. Ventur. 2013, 28, 373-396. [CrossRef]

39. Korber, S.; McNaughton, R.B. Resilience and entrepreneurship: A systematic literature review. Int. J. Entrep. Behav. Res. 2017, 24, 1129-1154. [CrossRef]

40. Liu, Y.; Cooper, C.L.; Tarba, S.Y. Resilience, wellbeing and HRM: A multidisciplinary perspective. Int. J. Hum. Resour. Manag. 2016, 30, 1227-1238. [CrossRef]

41. Baron, R.A.; Franklin, R.J.; Hmieleski, K.M. Why entrepreneurs often experience low, not high, levels of stress: The joint effects of selection and psychological capital. J. Manag. 2016, 42, 742-768. [CrossRef] 
42. Cardon, M.S.; Patel, P.C. Is Stress Worth it? Stress-Related Health and Wealth Trade-Offs for Entrepreneurs. Appl. Psychol. 2013, 64, 379-420. [CrossRef]

43. Liang, Z. The evolution of subjective well-being and its application in tourism research: A critical review. Tour. Hosp. Prospect. $2019,3,71$.

44. Nikolaev, B.N.; Maldonado-Bautista, I. Personality traits and income attainment of self-employed people-Accounting for model uncertainty. J. Bus. Ventur. Insights 2019, 11, e00111. [CrossRef]

45. Santoro, G.; Bertoldi, B.; Giachino, C.; Candelo, E. Exploring the relationship between entrepreneurial resilience and success: The moderating role of stakeholders' engagement. J. Bus. Res. 2018, 119, 142-150. [CrossRef]

46. Kim, P.H.; Longest, K.C.; Aldrich, H.E. Can You Lend Me a Hand? Task-Role Alignment of Social Support for Aspiring Business Owners. Work Occup. 2013, 40, 213-249. [CrossRef]

47. Giones, F.; Brem, A.; Pollack, J.M.; Michaelis, T.L.; Klyver, K.; Brinckmann, J. Revising entrepreneurial action in response to exogenous shocks: Considering the COVID-19 pandemic. J. Bus. Ventur. Insights 2020, 14, e00186. [CrossRef]

48. Kuhn, K.M.; Galloway, T.L. With a Little Help from My Competitors: Peer Networking among Artisan Entrepreneurs. Entrep. Theory Pract. 2015, 39, 571-600. [CrossRef]

49. Vissa, B.; Bhagavatula, S. The Causes and Consequences of Churn in Entrepreneurs' Personal Networks. Strat. Entrep. J. 2012, 6 , 273-289. [CrossRef]

50. Majchrzak, A.; Shepherd, D.A. Can digital innovations help reduce suffering? A crowd-based digital innovation framework of compassion venturing. Inf. Organ. 2021, 31, 100338. [CrossRef]

51. Kuhn, K.M.; Galloway, T.L.; Collins-Williams, M. Simply the best: An exploration of advice that small business owners value. J. Bus. Ventur. Insights 2017, 8, 33-40. [CrossRef]

52. Nambisan, S. Digital Entrepreneurship: Toward a Digital Technology Perspective of Entrepreneurship. Entrep. Theory Pract. 2017, 41, 1029-1055. [CrossRef]

53. Valenzuela, S.; Park, N.; Kee, K.F. Is There Social Capital in a Social Network Site?: Facebook Use and College Students' Life Satisfaction, Trust, and Participation. J. Comput. Commun. 2009, 14, 875-901. [CrossRef]

54. Kim, J.; Lee, J.-E.R. The Facebook Paths to Happiness: Effects of the Number of Facebook Friends and Self-Presentation on Subjective Well-Being. Cyberpsychol. Behav. Soc. Netw. 2011, 14, 359-364. [CrossRef] [PubMed]

55. Viseu, J.; Leal, R.; de Jesus, S.N.; Pinto, P.; Pechorro, P.; Greenglass, E. Relationship between economic stress factors and stress, anxiety, and depression: Moderating role of social support. Psychiatry Res. 2018, 268, 102-107. [CrossRef] [PubMed]

56. Every-Palmer, S.; Jenkins, M.; Gendall, P.; Hoek, J.; Beaglehole, B.; Bell, C.; Williman, J.; Rapsey, C.; Stanley, J. Psychological distress, anxiety, family violence, suicidality, and wellbeing in New Zealand during the COVID-19 lockdown: A cross-sectional study. PLOS ONE 2020, 15, e0241658. [CrossRef]

57. Shiri, N.; Mohammadi, D.; Hosseini, S.M. Entrepreneurial intention of agricultural students: Effects of role model, social support, social norms and perceived desirability. Arch. Appl. Sci. Res. 2012, 4, 892-897.

58. Park, E.K.; Martins, R.M.; Hain, D.; Jurowetzki, R. Entrepreneurial Ecosystem for Technology Start-ups in Nairobi: Empirical analysis of Twitter networks of Start-ups and Support organizations. In Proceedings of the DRUID, New York, NY, USA, 12-14 June 2017.

59. Tubey, R.; Nandwa, M.J.; Omboto, P.I.; Situma, C.M. Entrepreneurship climate and its effect on entrepreneurial development in Kenya. Int. J. Innov. Res. Dev. 2018, 4, 280-284.

60. Kang, H. Sample size determination and power analysis using the G*Power software. J. Educ. Eval. Health Prof. 2021, 18, 17. [CrossRef] [PubMed]

61. Fatoki, O. Entrepreneurial Stress, Burnout, Intention to Quit, and Performance of an Immigrant-Owned Small Business in South Africa. Int. J. Entrep. 2019, 23, 1-15.

62. Diener, E.; Wirtz, D.; Tov, W.; Kim-Prieto, C.; Choi, D.-W.; Oishi, S.; Biswas-Diener, R. New Well-being Measures: Short Scales to Assess Flourishing and Positive and Negative Feelings. Soc. Indic. Res. 2009, 97, 143-156. [CrossRef]

63. Frison, E.; Eggermont, S. The impact of daily stress on adolescents' depressed mood: The role of social support seeking through Facebook. Comput. Hum. Behav. 2015, 44, 315-325. [CrossRef]

64. Sinclair, V.G.; Wallston, K.A. The Development and Psychometric Evaluation of the Brief Resilient Coping Scale. Assessment 2004, 11, 94-101. [CrossRef]

65. Agneessens, F.; Waege, H.; Lievens, J. Diversity in social support by role relations: A typology. Soc. Netw. 2006, $28,427-441$. [CrossRef]

66. Mottram, A.J.; Fleming, M.J. Extraversion, Impulsivity, and Online Group Membership as Predictors of Problematic Internet Use. CyberPsychol. Behav. 2009, 12, 319-321. [CrossRef] [PubMed]

67. Lafuente, E.; Vaillant, Y.; Vendrell-Herrero, F.; Gomes, E. Bouncing Back from Failure: Entrepreneurial Resilience and the Internationalisation of Subsequent Ventures Created by Serial Entrepreneurs. Appl. Psychol. 2018, 68, 658-694. [CrossRef]

68. Calvo, J.C.A.; García, G.M. Established Business Owners' success: Influencing factors. J. Dev. Entrep. 2010, 15, $263-286$.

69. Johansen, V.; Foss, L. The effects of entrepreneurship education-does gender matter? Int. J. Entrep. Small Bus. 2013, $20,255-271$. [CrossRef]

70. Foley, A.; Griffith, B. Education, training and the promotion of high quality entrepreneurs in the Republic of Ireland. In Educating Entrepreneurs for Wealth Creation; Routledge: London, UK, 2018; pp. 80-92. [CrossRef] 
71. Podsakoff, P.M.; MacKenzie, S.B.; Lee, J.Y.; Podsakoff, N.P. Common method biases in behavioral research: A critical review of the literature and recommended remedies. J. Appl. Psychol. 2003, 88, 879. [CrossRef]

72. Hocking, R.; Pendleton, O. The regression dilemma. Commun. Stat.-Theory Methods 1983, 12, 497-527. [CrossRef]

73. Hair, J.F. Multivariate Data Analysis: A Global Perspective; Pearson: Hoboken, NJ, USA, 2010.

74. Preacher, K.J.; Hayes, A.F. Asymptotic and resampling strategies for assessing and comparing indirect effects in multiple mediator models. Behav. Res. Methods 2008, 40, 879-891. [CrossRef]

75. Mallinckrodt, B.; Abraham, W.T.; Wei, M.; Russell, D.W. Advances in testing the statistical significance of mediation effects. J. Couns. Psychol. 2006, 53, 372-378. [CrossRef]

76. Ratten, V. COVID-19 and entrepreneurship: Future research directions. Strat. Chang. 2021, 30, 91-98. [CrossRef]

77. Purnomo, B.R.; Adiguna, R.; Widodo, W.; Suyatna, H.; Nusantoro, B.P. Entrepreneurial resilience during the Covid-19 pandemic: Navigating survival, continuity and growth. J. Entrep. Emerg. Econ. 2021, 13, 497-524. [CrossRef]

78. Wright, T.A.; Cropanzano, R.; Bonett, D.G. The moderating role of employee positive well being on the relation between job satisfaction and job performance. J. Occup. Health Psychol. 2007, 12, 93-104. [CrossRef] [PubMed]

79. Miao, R.; Cao, Y. High-Performance Work System, Work Well-Being, and Employee Creativity: Cross-Level Moderating Role of Transformational Leadership. Int. J. Environ. Res. Public Health 2019, 16, 1640. [CrossRef] [PubMed]

80. Musters, D. The Effect of Percieved Stress (COVID-19) and Uncertainty Intolerance on the Entrepreneurial Decision-Making Process; Causation and Effectuation. Master's Thesis, University of Twente, Enschede, The Netherlands, 2021.

81. Branzei, O.; Abdelnour, S. Another day, another dollar: Enterprise resilience under terrorism in developing countries. J. Int. Bus. Stud. 2010, 41, 804-825. [CrossRef]

82. Dewald, J.; Bowen, F. Storm Clouds and Silver Linings: Responding to Disruptive Innovations Through Cognitive Resilience. Entrep. Theory Pract. 2010, 34, 197-218. [CrossRef]

83. Merion, I. Online Social Support: Just as Valuable as Offline Social Support? Ph.D. Thesis, California State University, Long Beach, CA, USA, 2017.

84. Kuckertz, A.; Brändle, L.; Gaudig, A.; Hinderer, S.; Arturo, C.; Reyes, M.; Prochotta, A.; Steinbrink, K.M.; Berger, E.S.C. Startups in times of crisis-A rapid response to the COVID-19 pandemic. J. Bus. Ventur. Insights 2020, 13, e00169. [CrossRef]

85. McMullen, J.S.; Shepherd, D.A. Entrepreneurial action and the role of uncertainty in the theory of the entrepreneur. Acad. Manag. Rev. 2006, 31, 132-152. [CrossRef]

86. Shepherd, D.A. COVID 19 and entrepreneurship: Time to pivot? J. Manag. Stud. 2020, 760176. [CrossRef]

87. Choi, S.; Lee, W.; Kang, S.-W. Entrepreneurial Orientation, Resource Orchestration Capability, Environmental Dynamics and Firm Performance: A Test of Three-Way Interaction. Sustainability 2020, 12, 5415. [CrossRef]

88. Nambisan, S.; Wright, M.; Feldman, M. The digital transformation of innovation and entrepreneurship: Progress, challenges and key themes. Res. Policy 2019, 48, 103773. [CrossRef] 